\section{What's New in Building Energy Research}
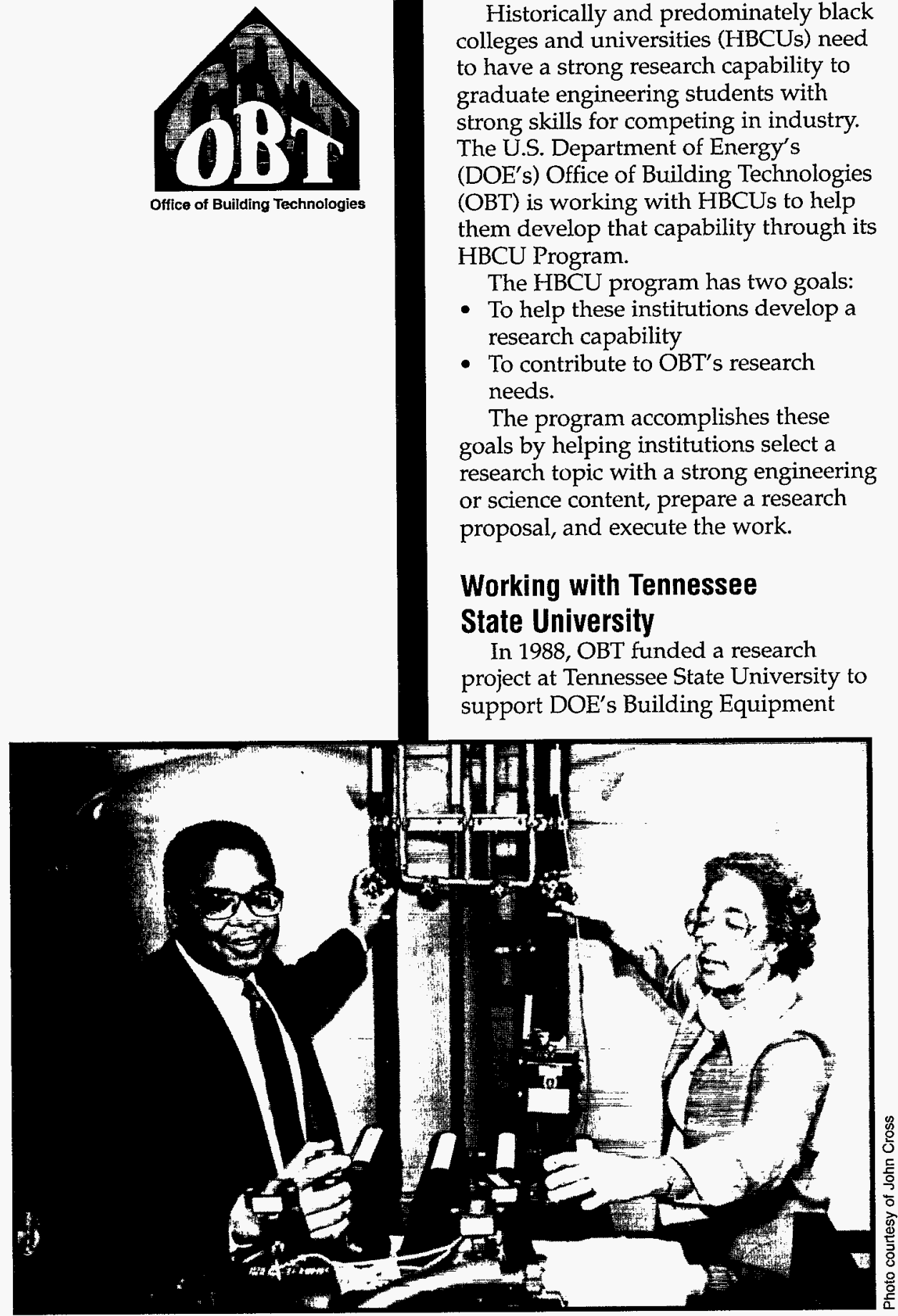

D.L. Hinton and Y.Y. Clark, principal investigators, test the equipment in the HVAC
Historically and predominately black colleges and universities (HBCUs) need to have a strong research capability to graduate engineering students with strong skills for competing in industry. The U.S. Department of Energy's (DOE's) Office of Building Technologies (OBT) is working with HBCUs to help them develop that capability through its HBCU Program.

The HBCU program has two goals:

- To help these institutions develop a research capability

- To contribute to OBT's research needs.

The program accomplishes these goals by helping institutions select a research topic with a strong engineering or science content, prepare a research proposal, and execute the work.

\section{Working with Tennessee State University}

In 1988, OBT funded a research project at Tennessee State University to support DOE's Building Equipment

\title{
HBCU Program at Tennessee State University
}

\author{
Minority engineering students research \\ heat pump refrigerants
}

testing laboratory.

Research Program. The objectives were to

- Provide an education benefit to graduate and undergraduate students by enhancing the thermal science program in the heating, ventilating, and air-conditioning (HVAC) area

- Establish experimental facilities and provide experience to support continuing HVAC research efforts

- Provide a testing laboratory for private firms that will ultimately become self supporting

- Support OBT's research mission through researching the performance characteristics of alternative refrigerants in heat pump cycles.

The university established a permanent HVAC testing laboratory and built an experimental closed-loop watersource heat pump to test replacement refrigerants for either HCFC-22 (hydrochlorofluorocarbon) or CFC-12 (chlorofluorocarbon). D.L. Hinton, Ph.D., and Y.Y. Clark, faculty members, directed graduate and undergraduate students in characterizing system performance for HCFC-22 and CFC-12. As a result, students have developed a good performance baseline for CFC-12 and characterized DuPont's ternary blend (R-22/R-152a/R-124) for automotive air-conditioning.

Researchers at Oak Ridge National Laboratory (ORNL) trained graduate and undergraduate students during summer internships. The experience greatly assisted the students in their respective laboratory tasks at the university.

In addition, Hinton has worked weekly with ORNL to develop analytical skills useful to the program objectives. He has completed studies of heat transfer characteristics of internal evaporation and condensation and presented results in three papers at meetings of the American Society of Mechanical Engineers. 


\section{Completed Work}

In fiscal year (FY) 1993, Hinton and Clark directed three graduate and two undergraduate students in the following work:

- Conducting a series of tests to demonstrate proper $\mathrm{CFC}-12$ refrigerant charge for the test heat pump

- Operating a test heat pump with the optimal charge for CFC-12 and characterized performance over a range of evaporation and condensing conditions simulating an automotive air-conditioning application

- Characterizing a substitute refrigerant for CFC-12, Du Pont's ternary blend, for an automotive airconditioning application and compared its performance to that of CFC-12

- Conducting optimal refrigerant charging tests for CFC-22

- Continuing analytical studies investigating the heat transfer characteristics of internally enhanced tube surfaces for mixed refrigerant evaporators.

In FY 1994, Hinton and Clark continued directing graduate students in characterizing the performance of HCFC-22. Specific tasks included

- Conducting a thermodynamic cycle analysis for DuPont's ternary blend using the Cycle-10 model

- Modifying the hardware to enable the test stand to test either CFC-12 or $\mathrm{HCFC}-22$ refrigerants and their respective substitutes

- Installing a new data acquisition system and new pressure and temperature instrumentation in the test stand

- Developing plans to design and build a supplemental heat transfer test stand that will focus on basic heat transfer and pressure drop data and design information for substitute refrigerants.

\section{Current and Future Work}

Current plans are to expand the program by moving into applied and fundamental research of alternative refrigerants. Clark and Hinton will direct graduate and undergraduate students in laboratory studies to characterize second-generation chlorine-free alternative refrigerants for vapor compression systems. FY 1995 and future work will include evaluating experimentally the $\mathrm{HCFC}-22$ refrigerant,

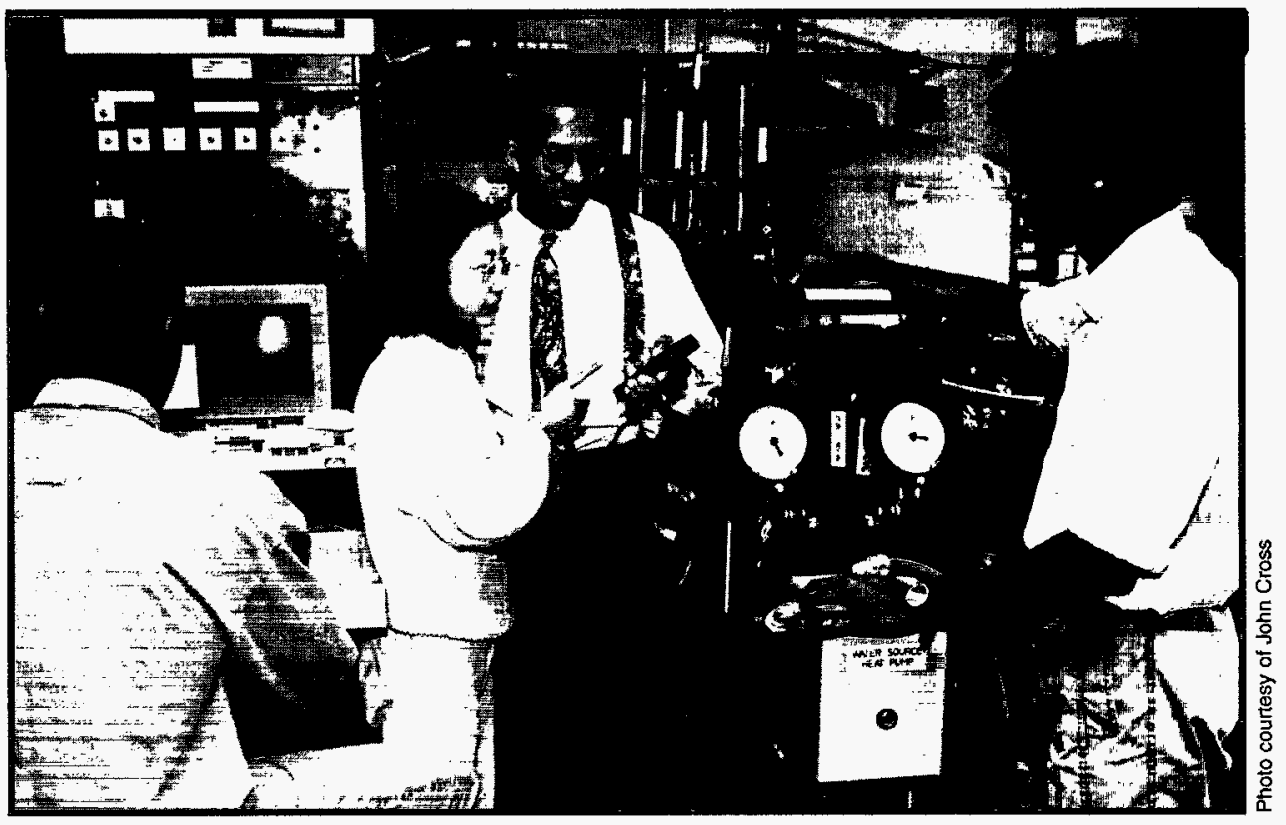

Engineering students Terryl Freeman, Gin Zhu, Wallace Edwards, and Ravikumar Subramanian work in the HVAC testing laboratory.

followed by potential substitutes. The students will analyze and test the candidate substitutes in the laboratory. Potential candidates include DuPont's R9000 (R-32/R-125/R-134a) and Allied Chemical's azeotropic blend of R-32/R-125.

The program will expand to include buying and installing a supplemental heat transfer test stand to measure basic heat transfer and pressure drop data for substitute refrigerants. Hinton will work with a graduate student to set up the test stand and operate the test loop with HCFC-22. After establishing a baseline, studies will expand to alternative refrigerants to $\mathrm{HCFC}-22$ or internal enhancement techniques or both.

\section{Measuring Program Success}

Several engineering students have gone through the program and landed jobs in industry. Greg Polk earned his Masters of Engineering in mechanical engineering and is employed by Inner City Products, Nashville, Tennessee. Gin Zhu completed her master's degree in mechanical engineering and is now working for Sharp computers in Memphis, Tennessee.

Darwin Lyons, Refolder Hennings, and John Owens completed their undergraduate training. Hennings later obtained a master's degree in mechanical engineering at Mississippi State
University and is now employed by EXXON in Dallas, Texas. Lyons and Owens are both in industry, employed by EXXON and ALCOA, respectively.

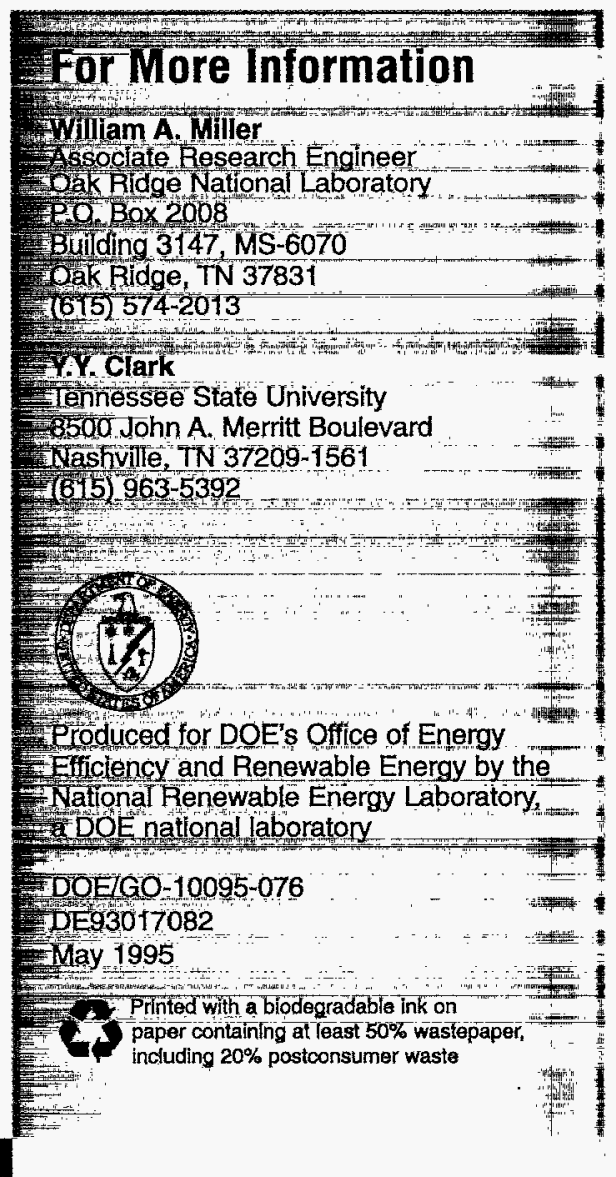




\section{DISCLAIMER}

This report was prepared as an account of work sponsored by an agency of the United States Government. Neither the United States Government nor any agency thereof, nor any of their employees, make any warranty, express or implied, or assumes any legal liability or responsibility for the accuracy, completeness, or usefulness of any information, apparatus, product, or process disclosed, or represents that its use would not infringe privately owned rights. Reference herein to any specific commercial product, process, or service by trade name, trademark, manufacturer, or otherwise does not necessarily constitute or imply its endorsement, recommendation, or favoring by the United States Government or any agency thereof. The views and opinions of authors expressed herein do not necessarily state or reflect those of the United States Government or any agency thereof. 


\section{DISCLAIMER}

Portions of this document may be illegible in electronic image products. Images are produced from the best available original document. 